\title{
Thinking and Prospect of Online Courses in Colleges in the Context of COVID-19
}

\author{
Yan Zheng* \\ Department of computer, Wuhan polytechnic, Wuhan 430074, China \\ *Corresponding author. Email: 6019463801@qq.com.
}

\begin{abstract}
The COVID-19 epidemic in the spring of 2020 has brought great changes and far-reaching impacts on China's economy, culture and people's life. The most significant impact it has brought to China's education is to accelerate the development from "traditional education" to "online education". The rapid transformation of numerous learning and training institutions and the vigorous development of various forms of online education under the guidance of education departments at all levels nationwide has made us rethink online education.
\end{abstract}

Keywords: Online teaching, Resource sharing, Information capability, Teaching capability, Teaching evaluation.

\section{INTRODUCTION}

Online teaching is a web-based teaching behavior. Influenced by COVID-19 outbreak, the Ministry of Education announced that delayed the start of the spring of 2020, advocated "closed on teaching and closed is not suspended," requires colleges and universities take full advantage of the desire of online classes and teaching resources of the province, two levels of school quality online courses, in class for resource platform and experiment platform service support, relying on the online course platform of all types and at all levels, the campus network learning space, etc., actively carry out online teaching and online teaching activities such as online learning, ensure the quality of epidemic prevention and control during the teaching progress and teaching.

\section{ONLINE TEACHING IN HIGHER VOCATIONAL COLLEGES IN THE CONTEXT OF EPIDEMIC PREVENTION AND CONTROL}

Since the first year of MOOC in 2012, online teaching has been playing a prominent role in China's higher education reform. In recent years, higher vocational colleges have been increasing the promotion of online teaching, which has effectively promoted the reform of vocational education and improved the quality of vocational teaching. Intelligent vocational education cloud and other teaching platforms are the outstanding ones in online course platform, while Wuhan Polytechnic chooses 8 platforms at the same time. It can be said that based on vocational teachers' unremitting efforts in online teaching in recent years, the online teaching practice in the epidemic prevention and control has reflected its due value in promoting the sharing of online teaching resources in higher vocational colleges, innovation of teaching mode, improvement of teachers' teaching ability and expansion of students' learning experience.

\subsection{Online Teaching in Higher Vocational Colleges in the Context of Epidemic Prevention and Control}

Since the first year of MOOC in 2012, online teaching has been playing a prominent role in China's higher education reform. In recent years, higher vocational colleges have been increasing the promotion of online teaching, which has effectively promoted the reform of vocational education and improved the quality of vocational teaching. Intelligent vocational education cloud and other teaching platforms are the outstanding ones in online course platform, while Wuhan Polytechnic chooses 8 platforms at the same time. It can be said that based on vocational teachers' unremitting efforts in online teaching in recent years, the online teaching practice in the epidemic prevention and control has reflected its due value in promoting the sharing of online teaching resources in higher vocational colleges, innovation of 
teaching mode, improvement of teachers' teaching ability and expansion of students' learning experience.

\subsection{Open and Share Online Teaching Resources}

Teaching resources are the basic guarantee for online teaching. In order to ensure the smooth development of the first large-scale and established online teaching in colleges and universities nationwide, the Ministry of Education requires all high-quality online courses and virtual simulation experiment teaching resources to be opened to colleges and universities nationwide free of charge. By February 2020, the Ministry of Education has organized 22 online course platforms to develop diversified online teaching solutions, including 1,291 national quality online open courses, covering 12 undergraduate disciplines and 18 professional categories for colleges and universities to choose from.

\subsection{Classroom Teaching Mode Innovation Can Be Widely Practiced}

Under the background of the epidemic prevention and control, in the "combining online learning and offline self-study", "online teaching in class, do a complete coverage of students", "to ensure that each student to participate in online teaching", "the study content includes ideological and political education courses, theory of public foundation courses, professional courses, virtual copy real operation course and epidemic prevention and control knowledge education" requirements, high vocational schools of all teachers and students in hubei province become the protagonist of online classroom teaching mode innovation practice. Teachers select suitable for class (MOOCs), exclusive online courses (SPOCs) and campus online course resources, application of public service platform, campus wisdom, teaching system and network learning space and the digital teaching software, to carry out online teaching, organize teaching activities such as online discussion, answer questions, online assignment, online test assessment of learning, such as widely used to flip the classroom teaching methods, the hybrid. Compared with the traditional teacher-centered and knowledge-impartating classroom teaching, the new teaching method can stimulate students' learning enthusiasm and initiative. The unprecedented scale of the practice, the form of a hundred flowers blooming, brilliant, indeed for the reform and innovation of higher vocational teaching mode has accumulated rich and fresh cases, basically realized the "school use platform, class use resources, everyone use space".

\subsection{Teachers' Teaching Ability Has Been Improved}

In online teaching, teachers are transformed from classroom lecturers into "guides" and "assistants", and the leading role of teachers is more reflected in "creation of learning environment, promotion of learning process and management of learning activities". In order to ensure the quality of teaching, it is necessary to improve the basic qualities of teachers in the reform and innovation of education philosophy, teaching design, teaching process, teaching strategy and teaching evaluation. Therefore, under the ministries and agencies organizations, the province's nationwide network of university teachers in higher vocational colleges make full use of the ministry of education training center "online" teacher development platform and three press, digital, electronic teaching materials, teaching courseware, teaching courseware teaching resources integration service advantages, pay attention to improve their online teaching skill training, and actively organize online teaching platform use training. According to statistics, as of February 28, the province's vocational colleges carry out online teaching of 8,403 full-time teachers, each school online teaching a total of 2,048 public basic courses, professional courses 10,359. At the same time, more important than teaching some knowledge and skills is that the majority of teachers actively respond to unexpected challenges, learn technology, use the platform, try to break through the online technology limitations on the communication between teachers and students. Teachers' sense of responsibility for their positions and careers in coping with challenges is not only a further and deeper education for students, but also a self-sublimation of professional spirit.

\subsection{Student Learning Experiences Are Expanded}

Gabriel kahn was published in the Wall Street journal in 2013, "2023 years of college would be like" the article said that 10 years after college, from the outside may be different from now, not much, but there in the classroom, curriculum, habits, textbooks, from five aspects, such as the cost of the experience of the students is fundamentally different from today. In the context of epidemic prevention and control, online teaching has provided Chinese college students with a brand new learning experience. At home, students can search for high-quality online courses on related topics through the Internet, get course resources such as electronic textbooks prepared by teachers from the teaching platform, and watch and learn from different nodes repeatedly. In online learning, students can develop personalized learning plans according to their own needs with the help of teachers, and carry out independent reading and thinking, thus becoming the main body in the learning process. 
The change of learning style expands students' learning experience. As students gradually adapt to and master the online learning mode, their ability to learn independently, communicate and interact, absorb and build knowledge will definitely increase.

\section{RETHINK ONLINE TEACHING IN HIGHER VOCATIONAL COLLEGES IN THE CONTEXT OF EPIDEMIC PREVENTION AND CONTROL}

Super-sized collective online education is a transitional way to keep learning and life as normal as possible in the face of the epidemic, but it is not a quick fix. Online teaching is not only the need of epidemic prevention and control, but also an important part of deepening the information-based teaching reform of vocational education at present and in the future.

\subsection{Concept first, Re-Understanding of Online Teaching in Higher Vocational Colleges}

Just as "the impact of information technology on the vocational education system is no longer a trivial tinkering, but a comprehensive systematic reform". Similarly, for higher vocational education, online teaching is not only the change of teaching form, but the only way to realize the open return of higher vocational education. In February 2019, the State Council issued the National Vocational Education Reform Implementation Plan, stressing that "vocational education and general education are two different types of education". Therefore, from the perspective of the characteristics of type education, Professor Jiang Dayuan proposed three characteristics of vocational education: cross-border, integration and reconstruction.

The author thinks that the openness of vocational education is the underlying logic of these three characteristics. The openness of vocational education is reflected in four aspects: "multiple subject participation" reflects the openness of school-running pattern, "industry-education integration, school-enterprise cooperation" reflects the openness of school-running pattern, thus bringing about the openness of learning field and education process. All open final realization path is professional and curriculum construction, online teaching is the only way. In recent years, higher vocational education has explored the reform of talent training mode, including the linking mode of middle and higher vocational education, the school-enterprise cooperation mode, the vocational education group mode combining work with study, and the informatization mode of "2+1+N" (2: two years of on-campus, online and offline combination; 1 . One year internship with combination of online and offline activities; N: After graduation, online lifelong learning), also deeply embodies the significance of online teaching in higher vocational education reform in practice. In the past and in the future, the construction of online courses in higher vocational colleges will continue to make further exploration in the combination of $1+X$ certificate and flexible enrollment teaching in higher vocational colleges.

\subsection{Integrate Introduction and Construction to Accelerate the Construction of High-Quality Online Teaching Resources}

Online learning is changing the way educational resources are allocated across society. In this epidemic, online teaching not only reflects its value, but also enlighten us to plan and build online education resources and platforms more systematically, and establish a scientific and efficient online course operation mode, so as to provide strong support for the continuous development of online teaching. Over the past decade, continuous investment has been made in the construction of online teaching resources. Recently, the quality and quantity of free online teaching resources in Hubei and even the whole country are first-class and considerable, providing a strong guarantee for online teaching during the epidemic prevention and control period. However, these resources are free of charge, and the former construction of provincial and national online high-quality courses resources focuses on the advantageous majors and courses of demonstration colleges, so the general colleges with a wide range of coverage will again face the shortage of high-quality online teaching resources and structural imbalance. As higher vocational colleges, the first is to expect the administrative department of education to give full play to the function of online teaching and education equality, and continue to accelerate the opening of resources; Second, it vigorously introduces the existing national quality resource bank resources and national and provincial quality MOOC, and carefully cultivates the construction project relying on the provincial online quality course construction project. Third, combine the professional advantages to intensify the cultivation of school-based exclusive online courses with distinctive features; Fourth, the use of information technology to strengthen the integration of resources, resource invocation and teaching interaction, behavior performance, data collection organic integration, in order to facilitate teachers and students to carry out independent learning, online interaction, live teaching.

\subsection{Implement Effective Classroom Certification}

The core competitiveness of higher vocational education lies in the quality of education, which mainly 
comes from the classroom. Classroom teaching reform is an important way to carry out education and teaching reform, improve teachers' professional ability and improve the quality of personnel training. The demand for "no time, no time" has made online teaching the mainstay of the classroom. The epidemic is not only a crisis, but also an opportunity for curriculum reform. It is an experimental field for the real scene of curriculum reform. Some problems of "teaching" and "learning" exposed in the current online teaching are actually the deep problems of curriculum reform, which need to be solved with the thinking of curriculum reform. Study the practice of carrying out online teaching in higher vocational colleges in Hubei is not hard to find, there is a common effective school characteristics, early implementation of the effective classroom certification - one for the teacher's teaching ability to enhance classroom teaching reform project, namely the teachers as the object of certification, for the certification of the carrier, with course in the classroom, for certification core, to project, information, education, and documentary evidence fusion (hereinafter referred to as "three integration") certification of the reform of teaching elements, through the certification for the whole, to create effective classroom, cultivate excellent teachers, system to promote the reform of the "three religions", to improve higher vocational teaching quality.

\subsection{Institutional Guarantee}

The development of online teaching quality evaluation brings about important changes in the relation of pedagogy, the subjectivity of students' learning becomes more prominent, the task of teachers guiding students' independent learning becomes heavier, and it also brings new topics to the evaluation of teaching quality. During the epidemic prevention and control, to ensure the quality of online learning and offline classroom teaching substantial equivalence, the managers of online teaching in higher vocational colleges teaching implemented online supervision, understand the interpretation of the online teaching, classroom interaction, resource quality, platform, etc., but how to scientifically effectively to online teaching quality evaluation need further elaboration and quantified. One is to establish the standards for the quality of online open courses, which will be incorporated into the talent training program. Second, the evaluation method of online teaching effect should be formulated, and the evaluation index system should be redesigned according to the characteristics of online teaching such as space separation and time asynchronism. Third, the value of teaching data should be fully mined to provide data support for online teaching evaluation. In teaching quality evaluation, we always adhere to moral education, integrate socialist core values into curriculum construction and evaluation standards, and constantly improve curriculum quality.

\section{CONCLUSION}

Online education is growing rapidly with the support of Internet technology, but it cannot replace traditional offline education due to the lack of interaction and lively discussion. Meanwhile, the standards of online education quality evaluation system also need to be formed. In order to improve the quality of education, it is necessary to combine online education with offline education, which complement and integrate each other. The offline education of schools and institutions is characterized by elite education and key education, while the online education of institutions using Internet technology is characterized by large-scale open courses. The two should complement each other and learn from each other.

\section{REFERENCES}

[1] Zhu yiming.Reflection on the Development of Online Teaching under the Situation of"Keeping Students Learning during Schools. Disruption".Education and Teaching Research[M]. East China Normal University.Shanghai.2020.3.

[2] LIU Zhentian.Some Considerations on Emergency Online Teaching.Higher Education studies in China [M].2020.4.

[3] Yu xinjie.High quality online teaching to cope with the epidemic prevention and control in colleges and universities. Youth Focus [M].2020.4.

[4] Wang xueyan, Zhangqiang. Problems and countermeasures of ideological and political course teaching in universities under the epidemic situation.Fujian tea[M].2020.4.

[5] http://k.sina.com.cn/article_5675440730_152485a5 a02000rqxl.html.

[6] http://www.fx361.com/page/2020/0508/6633211.sh tml. 